\title{
SUSTAINABLE URBAN PLANNING IN DEVELOPED COUNTRIES: LESSONS FOR TURKEY
}

\author{
KADIR HAKAN YAZAR ${ }^{1} \&$ OKAN MURAT DEDE ${ }^{2}$ \\ 1“Modern Planlama" Şehircilik Mühendislik ve Danışmanlık A.Ş., (Urbanism Engineering, Consultancy Inc. Co.), Ankara. \\ ${ }^{2}$ Amasya University, Faculty of Architecture, Department of City and Regional Planning, Amasya.
}

\begin{abstract}
Publicly announced first in 1987, sustainable development became one of the most important subjects of academic, political, and philosophical debates of the 21st century. Based on the philosophy of respect to the needs of further generations, it is a model of continuing and balanced development. Implementation of sustainable development could be monitored best in urban areas as most of the world population is now living in cities. This concept also becomes very important in urban planning, as planning is almost the only tool to prevent an undesirable future for urban areas. It is acknowledged that sustainable urban development could only be achieved by sustainable urban plans. In this respect, urban planning tradition should change in line with sustainable urban development and all countries should adapt their planning traditions to sustainable urban development. In this article, examples of sustainable urban plans from the United States and Europe are presented as a model for sustainable urban planning in a developing country like Turkey. Common characteristics of these sustainable urban plans are determined in this article, in order to contribute to sustainable urban planning methods for Turkish cities and for the cities of other developing countries.

Keywords: sustainability, sustainable city plans, sustainable urban development, sustainable urban planning, Turkish urban planning system.
\end{abstract}

\section{INTRODUCTION}

Cities undergo an important transformation process due to the changing socio-economic conditions worldwide. In this process, the most important problems that cities and urban administrations confront are related to the ways to sustain the scarce resources of cities and urban development, and utilize natural, cultural, and historical values. As these developments could not be maintained spontaneously, they necessitate effective sustainable urban policies.

On the other hand, economic, social, and cultural diversities such as size of the cities and various geographic conditions require different transformation types for the cities. Although the problems of each city could differ greatly from those of another city, cities are affected by similar circumstances and some common problems. Urban policies should deal with negative externalities, such as environmental pollution, social tensions, and socio-economic polarization.

In order to prevent these negative conditions and maintain the future development of cities, sustainable development becomes a critical concept. However, a standard sustainable development prescription for all cities does not exist as they have different development levels and socio-cultural characteristics. For example, most cities of the developed world offer better living standards in contrast with the cities of the developing countries. On the other hand, cities of the developing countries show lower levels of resource exploitation, greenhouse gas emission, and garbage amounts per person. Thereby, specific problems of each city necessitate the constitution of sui generis urbanization policies.

New policies that cities develop should be based on the concept of sustainable urban development. As the concept is so broad and is related with various areas, it is an intangible one. Therefore, the concept should be concretized in order to use it to solve urban problems.

Sustainable development could be best analysed and applied in urban areas, as nowadays the majority of the world population is living in cities. Urban planning seems to be the most important 
tool for integrating sustainability issues in urban development. Concerns about sustainability bring about the necessity of a new type of planning tradition and new planning approaches differing from the conventional and traditional urban planning approaches known as classical or orthodox urban planning. This new planning approach could not be defined as a unique type for the whole countries. Its application differs between cultures according to various characteristics of the society.

The aim of this article is to take a hint for a new urban planning model for Turkey by using examples from the developed countries, especially the USA and European countries, to show different sustainable urban planning applications.

The first part of this study briefly presents the development of the sustainability concept and sustainable urban development. Then, the importance and aspects of urban planning are discussed. After presenting the sustainable urban planning examples from the USA and Europe to understand how sustainability enters into the urban planning process for achieving a sustainable future for urban areas, the current urban planning practice in Turkey is identified. In light of these developments and examples, in the last section, it is sought to formulate a sustainable urban planning process for Turkey.

\section{THE EMERGENCE OF SUSTAINABLE URBAN DEVELOPMENT}

The increasing environmental problems and environmental movements made the sustainability concept valid for all aspects of social life in the 1960s and the 1970s, although the history of sustainability thought could be traced back to ancient Greek in the writings of Epicurus [1] and some Eastern Cultures, like ancient India [2]. Besides, there were applications of sustainability in history. The book of Hans Carl von Carlowitz, "Silviculture and Economics" of 1713 - which is considered to be the first work on forest management - takes up the idea of "sustainability" [3]. Moreover, the applications of sustainability could be observed in the fishery sector since the beginning of the 20th century [4]. However, sustainability as a global policy dates back to the 1970s. There are some important milestones of the development of sustainability thought at a global level at the end of the 20th century. These can be listed as:

- The UN Conference on Human Environment, also known as the Stockholm Conference in 1972.

- Habitat I Conference in Vancouver in 1976.

- Publication of World Conservation Strategy in 1980.

- Work of the World Commission on Environment and Development known as the Brundtland Commission in 1987.

- The Earth Summit or the UN Conference on Environment and Development in Rio, in 1992.

- Habitat II Conference held in Istanbul in 1996.

- Johannesburg meeting in 2002.

Warnings about urbanization were made at the Stockholm Conference in 1972, as principle 15 of the final declaration states: 'Planning must be applied to human settlements and urbanization with a view to avoiding adverse effects on the environment and obtaining maximum social, economic and environmental benefits for all' (Principle 15) [5].

At Habitat I Conference in 1976, governments began to recognize the consequences of rapid urbanization, especially in the developing world, because the world was starting to witness the greatest and fastest migration into cities and towns in history [6].

The Brundtland Report published in 1987, also known as Our Common Future, was the first document to define the sustainability concept. This report brought to light the importance of urban areas for maintaining sustainability for the whole world. This is the first document that gives advices on sustainable urban development, although the use of the concepts like sustainable urban development and sustainable city was not direct. In the Urban Challenge section of the policy directions, it 
is stated that governments will need to develop explicit settlement strategies to guide the process of urbanization taking the pressure of largest urban centers and building up smaller towns and cities more closely integrating them with their rural hinterlands [7]. The Brundtland Report is an important official document that started the decentralization and governance debates. After the Brundtland Report on 'Our Common Future', the significance of sustainable development increased rapidly both at international and at national levels [8].

All of the following international acts emphasized sustainability - urban development interaction. For example, the Sustainable Cities Program was established in 1991 [8]. This program had a key role in the application of the upcoming Agenda 21, one of the most important outcomes of the Rio Conference in 1992, and the application of Habitat Agenda.

Local Agenda 21 accepted in Rio Conference has a special importance that it could be accepted as the primary mechanism for the application of sustainable development at the local level. This shows that urban areas became the focus of sustainable development policies starting from the 1990s.

Habitat II is important as it includes 'sustainable human settlements' among its main commitments [9]. Global action in Habitat's Agenda focuses on several points, including sustainable land use, population and sustainable human settlement development, environmentally sustainable, healthy and livable human settlements, and so on [9].

The mid-1990s was the period in which urban planners were introduced a new term for urban development: sustainable urban development. In the subsequent publications of the UN in 2001, it was called a 'changing paradigm' for urban development [9]. The Hong Kong Declaration on Sustainable Development for Cities, announced by the UN within the concept of 'sustainable urban development' in 2004, could be accepted as a minor milestone for widely spreading sustainable urban development discussions [10]. The main topics in this declaration were integrating sustainable development into city and regional planning, identifying new mechanisms for implementing sustainable development measures, realizing appropriate urban governance for the quality of life in cities, encouraging participation of citizens in policy discussion, decision-making, and implementation and raising awareness of sustainable development through education.

After these global efforts, sustainable urban development became the key factor for all urbanrelated discussions. Although the starting point of sustainable development was not directly related to urban issues, in time it traced as a new approach for all human settlements. The main concern of sustainability is that development should meet basic human needs [8]. As the majority of the population is living in urban areas, the main area of concern naturally becomes the urban areas. After the early 1990s, sustainable urban development has started to take place in the related literature frequently with the main research questions: How sustainability of urban areas can be achieved? Is it sufficient to take urban areas as the focal point of sustainability? Is there a unique sustainable urban development procedure in the world?

There are various reasons for supporting that urban areas are the key to sustainable development. These are the importance of cities for maintaining economic and social development at national and local levels, the agglomeration of population in cities even in the non-developed countries, the importance of cities in employment, housing and service supply, and the massive environmental damage spread from cities to all around.

Urban areas are open systems that also have effects on remote areas [11], so sustainable development policies are made at local and regional levels. Moreover, the local is the best level to easily reach sustainability goals [12].

After the rise of sustainable development owing to the international efforts, all the related academic discussions were concentrated on the definition and on the central tenets of sustainable urban 
development. First, the urban aspects of basic sustainable development targets are grouped in economic, social, and environmental dimensions. Second, the concept sustainable urban development simultaneously developed with sustainable development and is shaped by the reflections of principles, policies, and actions on space. Since the 1990s, sustainable urban development has become the main policy field globally for the integration of economic, social, and environmental development at the urban level for creating cities of future.

For van Geenhuisen and Nijkamp, sustainability at urban level identifies a new potential to reach new socio-economic, demographic, and technological development levels with supporting environmental conditions [11]. It is obvious that the increasing poverty in urban areas will make sustainability concept more oriented to urban sustainability.

\section{URBAN PLANNING FOR SUSTAINABLE URBAN DEVELOPMENT}

As Rosales stated, 'Urban planning is closely related both, to decision-making processes as well as to the establishment of a further urban envisioning' [13]. It is a tool for managing and changing of natural environment into built environment. If one looks to urban sustainability from the ecological side, built environment itself contradicts sustainability. In this respect, the importance of urban planning is in realizing the targets about sustainable urban development. Urban planning could play a vital role in ensuring sustainable urbanization [14]. An important discussion topic arises: How could urban planning be organized for achieving sustainable urban development, and what will be the role of planning in sustainability?

There are various dimensions of urban planning related to sustainable urban development, such as (a) sustainable urban models, (b) structure of planning and planning procedures, and (c) stages within planning processes.

The first dimension is related to the sustainable urban models that fit best sustainable development. Wheeler, in 1998, identified several directions that should be taken for sustainable urban development:

- compact, efficient land use;

- less automobile use, better access;

- efficient resource use, less pollution, and waste;

- restoration of natural systems;

- good housing and living environments;

- a healthy social ecology;

- a sustainable economics;

- community participation and involvement;

- preservation of local culture and wisdom [15].

In order to maintain sustainable urban development, several urban models were developed by scholars. These could be classified between light green (balancing environmental and economic issues, distribution of wealth among all classes in the society) and deep green (contrary to major economic expansion) models and the intersection models between these two basic models [16].

The second issue is related to the changing structure of planning for maintaining sustainable development of urban areas, which has become the most popular academic research interest since the 1990s. It is stated that the existing urban planning system as a tool of urban development aiming only at economic development is not possible within existing conditions related to land use, built environment, and infrastructure [17]. The document "Planning Sustainable Cities: UN Habitat Practices and Perspectives" published in 2010 is important in that it shows the trend that sustainability discussions are now oriented toward the planning issues of human settlements [18]. 
The discussions on sustainable development at the international level underline the new governance systems and set out participation as the primary condition for effective decision-making. This situation emphasizes the importance of participation in urban planning. Only community or citizen participation itself would necessitate radical changes in conventional urban planning processes.

A conflict seems possible between the new planning approaches and the existing institutional structure that is built on the current conventional planning approach [19]. UN Habitat identifies this condition as reinventing urban planning for sustainable cities [18]. The principles of new urban planning are promoting sustainable development, achieving integrated planning, integrating plans with budgets, planning with partners and stakeholders, meeting the subsidiary principles, promoting market responsiveness, ensuring access to land, developing appropriate planning tools, being pro-poor and inclusive, and recognizing cultural diversity [18].

By the factors side, "proper urban planning is the key to bridging the urban divide and is an essential tool to make cities inclusive, environmentally friendly, economically vibrant, culturally meaningful and safe for all" [18]. Moreover, it is stated in the UN document that planning approaches are switching from the command and control model and becoming more strategic, selective, and oriented to guide rational investment planning, which is environmentally conscious and accrues benefits for the whole community [18].

New planning initiatives try to address some definite problems in traditional master planning systems. Instead, these new initiatives bring their own structural adjustments instead of the older ones. These are listed as [14] follows:

- strategic rather than comprehensive;

- flexible rather than end-state oriented and fixed;

- action and implementation oriented through links to budgets, projects, and city-wide or regional infrastructure;

- stakeholder or community driven rather than only expert driven;

- occasionally linked to political terms of office;

- contain objectives reflecting emerging urban concerns - for example, city global positioning, environmental protection, sustainable development, social inclusion, and local identity;

- play an integrative role in policy formulation and in urban management by encouraging government departments to coordinate their plans in space; and

- focus on the planning process, with the outcomes being highly diverse and dependent upon stakeholder influence or upon local policy directions.

Naess in his article in 2001 stated that planning for sustainable development should be goal oriented. The rational comprehensive model is appropriate to this condition, but it lacks the participation factor and its methods of analysis neglect factors that cannot be evaluated in monetary terms. Moreover, it does not regard the distribution between individuals and groups [20]. Instead of this, he supported communicative planning which emphasizes citizen participation and consensus on sustainability issues between various groups of the society. This planning approach is similar to collaborative planning as Healey advocates [21]. One of the most important characteristics of communicative planning approach is described as rather than $r$ ejecting expert knowledge, planning for a sustainable development should make use of both expert and layman knowledge, and involve perspectives from natural, technological and social as well as human science [20].

Professor Cliff Hogue compared the habitat Agenda with the orthodox ideas of town planning. The most striking aspects of this comparison are the role of state which becomes weaker, the 
existence of governance systems, instead of long-term plans, and the role of professionals as being enablers and partners instead of being experts [22].

The third and the last issue is related to planning techniques, procedures, and stages used during the planning process, which are strictly related to the new planning approaches. The factors affecting the changes in urban planning practice, such as citizen participation, necessity of monitoring, and sustainability indicators, make the planning procedure different from the comprehensive, conventional planning style depending totally on expert decisions.

As mentioned above, there are three different factors causing changes in planning procedures. These are citizen participation, use of sustainability indicators, and monitoring process. Participatory processes should take part in planning processes as one of the inevitable principles of planning for sustainable urban development. It is claimed that public participation encourage an innovative process that guarantees the efficiency of sustainable urban planning and promotes a sustainable new way of living in any community [23].

The second factor is the newly developing 'sustainability indicators'. Economic and environmental conditions require a broad set of urban planning instruments toward sustainability [13]. In this respect, the use of sustainability indicators in urban planning becomes inevitable. Rosales defines sustainability indicators as ex ante tools in urban planning and as useful instruments that guarantee urban sustainability in all its dimensions [13]. These indicators could be grouped as economic, social, and environmental indicators and fulfilling these indicators became the main goal in the new planning approach, instead of the targets put by planning experts in traditional/conventional urban planning processes. The first effort to develop urban sustainability indicators took place at the Aalborg Conference in 1994; the first conference on European Sustainable Cities and Towns - 6 was held until 2011. The need for these indicators was emphasized at the conference [24].

The third factor is the monitoring process which gained importance in whole planning process in order to test whether the sustainability goals are achieved or not related to the sustainability indicators. Evaluation matrices and feedbacks became inevitable parts of the entire planning process.

Indeed, the 21 steps for a healthy and sustainable urban planning process in Local Agenda 21 include community participation (stage 1), monitoring procedures (stage 5), and selection of indicators for measuring sustainability progress (stage 6) [25].

\section{SUSTAINABLE URBAN PLANNING EXAMPLES FROM THE DEVELOPED COUNTRIES}

Application of sustainable urban planning is a rather recent concept. While the sustainable urban planning is different from the orthodox urban planning approach the end product, a city plan is somehow the same. There are some advantages of the economically advanced nations in applying new planning approaches as they have more innovative capacity necessary for sustainable development and have more adaptive social and administrative structures for adopting sustainable planning. In this respect, three sustainable urban planning examples from the USA and three examples from Europe are chosen to identify the direction of urban planning. All these examples have different characteristics and are known as successful sustainable urban planning applications among which some were awarded for sustainability.

\subsection{Sustainable urban planning examples from the USA}

A common opinion about the policies in USA is that they are not associated with debates on environmental problems. In fact, the attitude of the country concerning the Kyoto Protocol supports this type of opinion. However, with the Rio Summit, 1992 elections, and with the studies of the World 
Architectural Union during the 19th General Assembly held in Chicago, important changes emerged concerning the attitude of the country and environmental consciousness became the first issue among American urban planners [26].

In the USA, where approaches to environment started to change during the 1990s, sustainability was considered together with the concepts of new urbanization and smart growth in the field of urban planning. In this respect, smart growth supports social livability that envisages development of life quality with respect to environment and sensitive to economy [27].

Cities of Asheville, Stapleton, and Austin were chosen as the US examples for sustainable planning studies.

\subsubsection{Asheville}

Asheville is a midsize American city located in North Carolina with a population of 110.000 and has the lowest population growth ratio among the cities of the state [28].

The first important point in the plan is that it was prepared by the 'Urban Plan Consultation Committee' formed by different groups in the city. Citizen participation could be considered as the key concept of the plan. In the plan preparation period, forums were held with the participation of urban dwellers and the tendencies of the dwellers were defined. In addition, internet pages were organized to increase the rate of participation. According to the Plan Report [28], this process continued for one year. It was also claimed that with the existence of such a committee, higher levels of public participation were achieved. In the Plan Report, it is emphasized that planning decisions were taken totally in line with the society's opinions [28].

The Plan of Asheville was an advisory in nature for decision-making process rather than being an ultimate decision-maker document. It was prepared according to the principles of smart growth. The plan consisted of six parts and three appendices: initiative of vision and smart growth, communication and coordination, land use and transportation, air and water quality, economic development and urban services parts, urban center with appendices of application matrix, updating and application appendices [28].

The application matrix is one of the most important parts of the plan. It was prepared to speed up the application process and to make the plan more effective. In this respect, all aims and strategies were assigned to the appropriate urban levels. Time levels are determined to achieve these aims and participation models for relevant aims and strategies were shown. The matrix helps to ease the process of monitoring. The plan is projected to be flexible and the importance of yearly feed backs is pointed out for checking the application process. For this process, budget conditions should fulfill the situation and the revision of the whole plan could be done every five years [28].

The Asheville Plan proposes important sustainable land use and transportation policies within the direction of smart growth such as supporting mixed-use development, conservation of conventional neighborhoods, infill development of residential and commercial areas, use of industrial areas only for industry, flexible design efforts, supporting mass transit, and priority of bicycle [29].

\subsubsection{Stapleton}

The second example from the USA is Stapleton located near Denver and has a population of 108.000. In the Stapleton Urban Growth Plan, known as Green Book [27], sustainability is considered a tool for supporting the application approach rather than a basic philosophy. In this respect, the aim of the plan is to realize the aim of a sustainable vision for the society.

In respect, as the plan is based on sustainability principle; it will emphasize the satisfaction of the needs of the next generations as well as increasing the life quality of the current population. On the other hand, this approach has common emotions and recognition compulsory for the longevity of natural sources [30]. 
According to the plan report, education is central to the sustainable thought as it is claimed that sustainability is a vision of society as an important target and has to be evaluated within the social memory and culture [30]. The Stapleton Plan was awarded the prestigious Stockholm Participants Award. It was said to bring urban sprawl to an end and referred as a courier to start debates on landuse decisions that depend on detached housing units and automobile-oriented transportation [31].

The Stapleton Plan was the part of Comprehensive Denver plan and had nine key areas. These were presented separately in the plan report and targets were defined for all these areas among which education, land-use design, waste management, and transportation. Land-use design takes an important part in this plan. It aims a comprehensive and mixed-use-based design for different inhabitants of the city for supporting their ways of living [31].

The Stapleton Plan was designed as a guide and a source in all steps of the planning process and was seen as a living document with the city. It is emphasized that the plan could be re-organized, if targets were not practical, productive, and economic within the referred period. As a planning method, actions and programs took place at the end of each part of the plan. A strong feedback process exists in the planning process.

\subsubsection{Austin}

The last example from the USA is Austin located in Texas State. A sustainable urban plan was prepared for Austin by the City Council within the context of Agenda 21 [32]. With its population of 400.000 , it is larger than a midsize city.

In Austin, smart growth was the basic concept and education was given extra importance through sustainability. In this respect, particular attention was paid to mass media and internet communication.

One important aspect of the Austin Plan is the sustainability matrix that is required at the end of the plan. This matrix is used for evaluation of the projects of the urban area through sustainability. This evaluation includes the dimensions of environment, justice, and economy and proposes a systematic approach.

The main approach of the matrix is to define priorities of the projects and to put them into time series. In this respect, the evaluation of various planning alternatives was done according to 13 different indicators: public health and security, maintenance and conservation, socio-economic impact, neighborhood effect, social justice, alternative fiscal sources, harmony with other projects, land use, air, water, energy, biological, and other environmental effects [33].

In the evaluation, the impact index of each indicator is used. Table 1 shows an example table for the sustainability matrix. There are impact indicators, component factors that identify social, economic, and environmental characteristics of the criterion, and weight factor assigned to these criteria. Different weight values were assigned to the criteria and the evaluation of various alternatives was executed in the matrix [33].

The sustainability matrix is composed of the following stages [34]:

- formation of account table and sending it to all urban units,

- pointing out project offers sending them to environmental conservation unit,

- re-evaluation of the matrix and giving a common decision with the unit which prepared the matrix,

- putting the project into sustainability order according to total points of the project,

- re-arranging sustainability order according to economic applicability analysis,

- determining application order of the projects.

In this respect, the sustainability matrix functions as an application tool that evaluates probable consequences of the projects before their application. It contributes to the right use of resources with 


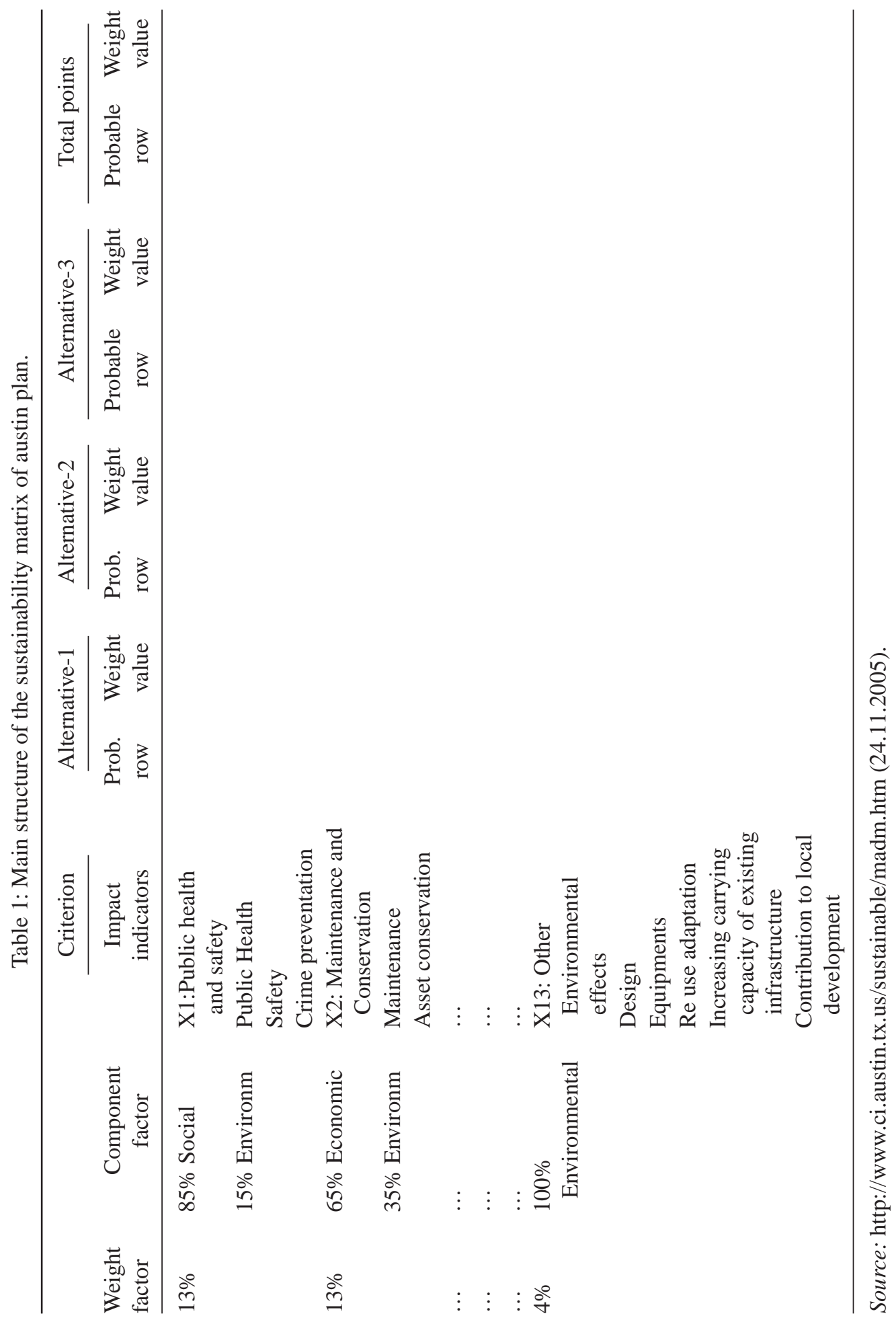


correct determination of prior subjects for the society. On the other hand, as the plan is a frame plan, it is prepared as a bundle of projects instead of bringing decisions about every subject. These characteristics provide convenience in the application of the matrix.

\subsection{European examples of sustainable urban planning}

In Europe, especially in the last 20 years, various urban problems like enlargement of large cities, social segregation, environmental and transportation problems, and degradation in city centers are observed. Spatial planning is considered a key tool by many authorities in order to solve these problems and maintaining sustainability at local levels [35].

Urban planning systems differ from country to country in Europe. All countries have different legal and administrative systems and consequently, diverse planning systems. However, if it is generalized, it could be observed that there are three main planning systems throughout Europe. These are [35] centralized planning system, balanced distribution of responsibilities to administration types and units, and completely decentralized systems.

In this respect, despite different views, urban planning systems indicate three different functions:

- Long pan strategic plan that depends on the evaluation of strong and weak aspects and provides an integrated vision for future.

- National, regional, urban, and neighborhood plans that are shaped by planning process. These plans contain comprehensive plans; strategies, policies, projects, buildings, actors, land use, settlement scheme, residential, commercial, tourism, and transportation schemes.

- An approach that depends on the development of control including legal and administrative processes at local levels to determine the location and form of development.

The European examples of sustainable urban planning are Cork City from Ireland, Drammen from Norway, and Heidelberg from Germany.

\subsubsection{Cork City (Ireland)}

Cork City is an Irish city with a population of 120.000 located in the South of Ireland. The City Development Plan is shaped by the National Spatial Strategy and Cork Strategic Plan according to the Irish National Planning hierarchy. In this context, Cork Strategic Plan for 2020 was prepared before the Cork Development Plan. In the National Spatial Strategy, Cork is defined as a nodal point for the economic base of Southwest Ireland [36]. After the strategic plan, the city development plan was prepared.

In the strategic plan, strengths and opportunities of the city were listed. Mixed-use development, high-density development wherever appropriate, supply of qualified mass transportation, qualified environment, and high-quality urban design were defined as the key sustainable development potentials of the Plan. The City Development Plan aims at social integration, equal accessibility to employment, transportation, education, social, and cultural facilities, reaching a high-quality level of life with natural and man-made environment. The sustainability oriented City Development Plan of Cork City consists of two main units: the main plan and the record of conserved structures [37].

The Main Plan is a comprehensive one with 10 sections. Environmental evaluation as the last section has a significant importance for sustainability. Environmental evaluation is described as an evaluation process of the plans, policies, programs, and efforts related to environmental results.

Moreover, another significant aspect is the Policy Evaluation Matrix as shown in Table 2. In the Policy Evaluation Matrix, formed within the plan, policy fields are evaluated, respectively, with 
Table 2: Policy evaluation matrix.

\begin{tabular}{lcccc}
\hline & & \multicolumn{3}{c}{ Environ- } \\
Policy headlines & Energy & Non- & Environ- & mental \\
productivity & resources & mental & quality and & Human \\
protection & character & comfort \\
\hline
\end{tabular}

General Policies

1. Strengthen national transition role of the city with maintaining sustainable growth

2. Maintain social integration and increase accessibility to social and cultural facilities

3. Increase life quality in the city and maintain high-quality natural and man-made environments

Strategic Aims

1. Condition the future development in frame of land use and transportation defined in strategic plan

2. Differentiate economic sectors and maintain sustainable economic growth and create employment opportunities

$\begin{array}{ll}* & \\ \ldots & \\ \ldots & \\ * & \\ * & \end{array}$
opment of suburb areas

8. Eegeneration of city centers and dock areas

9. Maintain sustainable devel-

10. Guarantee right development of cities with development control policies and standards

$\mathbf{X}$

$*$

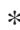

$*$ o

o

$\cdots$

o

o

? o

o

*

o

*

$*$

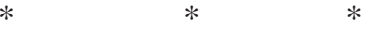

* * *

Source: http://www.corkcity.ie/ourservices/planning/developmentplan/download.html (04.07.2006). 
positive, negative, neutral, and ambiguous symbols. The final stage of the plan consists of the feedback and monitoring processes. These processes will continue during the implementation of the plan.

The latest step of the plan consists of feedback and monitoring processes. It is claimed that the related processes will last through the application period of the plan.

\subsubsection{Drammen (Norway)}

The second example from Europe is the City of Drammen from Norway; a mid-size city. Drammen's population was approximately 50.000 in 2005 and functions as a transportation hub in the region [38].

Drammen Master Plan was accepted by the City Council in 2003 and targeted the year 2014. The plan has two components which are short term and long term. The long-term component arranges the targets for the development of the municipality, a guide for sectoral planning, land use for land management, and conservation of natural sources. The short-term component states the integrated action programs for every 5 years. The land-use part of the plan is the legally binding feature. The Plan was prepared with a high rate of participation of several groups like politicians, entrepreneurs, regional authorities, and many other specialist units. The plan was oriented for the implementation of sustainable development values in a welfare society. The selection of the best image was the most important part in the construction process of the plan [38].

There were four images determined to define the future development of the Drammen city. These images are as follows [38]:

- A city with no vision: people do not invest for the future and there is status of only the temporary regulations.

- Naturbania: culture concept is seen as a new type of industry and there is an existence of an information economy. Compact city and strict conservation of natural areas are other foresights of this image.

- Hub: it depends highly on transportation characteristics as well as high accessibilities and a perfect physical infrastructure is expected.

- Neighborhood life: a decentralized image is accepted which depends on the housing units and family life. In addition, high-quality of life and accessibility are expected.

Consequently, the plan started with discussions about the perceptions of the city and the best image for the city instead of the conventional analysis section of the traditional comprehensive planning. As a result of this approach, the plan started from a synthesis process. After this stage, the predicted consequences of each image were examined in detail and this process was called the analysis stage. At the last stage, one image was selected and this became the basis and core of the Master Plan decisions. On the other hand, a new approach of synthesis-analysis-synthesis process in planning system depends heavily on broad and active participation. An important dimension of the participation is that this process was completed within 2.5 years [38].

\subsubsection{Heidelberg (Germany)}

The last example from Europe is Heidelberg, Germany. Heidelberg is in the World Heritage list of UNESCO (United Nations Educational, Scientific and Cultural Organisation) and has a population of 140.000 [39].

The City Plan of Heidelberg was prepared by the City Council in 1997. The 2010 Heidelberg Urban Development Plan was updated by the city council in 2006 and the process up to 2015 was revised. The reason for this update was declared as demographic changes [40]. 
This plan defines main aims of the urban policy toward the 21st century within Local Agenda 21. For this reason, the city of Heidelberg was chosen as a pilot city in the research Project of "Cities of Future". The City Development Plan, which deals with all dimensions of social life, was prepared within the understanding of modern urban development policy, and it exhibits a comprehensive action framework. The main characteristic of the Plan is the sustainable urban development concept as its basis explained in Agenda 21 [41].

With the plan, a city with short distances was tried to be created. Other foresights of the plan were full utilization of inner sources, efficient use of spaces, and high participation ratios. The most striking aspect of the Heidelberg plan is the methodology for monitoring of planning decisions. This monitoring process, called the Sustainable Development Report, was defined as the second phase of the plan [40].

The monitoring stage was included in the process after the application of the plan and evaluations are done every 3 years. The changes in different sectors (urbanization, employment, housing, environment, culture, demographic change, etc.) are evaluated according to the targets of the plan. Five different stages are determined with respect to these changes and every sector is evaluated through the direction of change. These stages and their symbols are as follows [42]:

-- : intense deterioration (deviation exceeds 10\% from target);

- : less deterioration or deterioration in some conditions (deviation between $1 \%$ and $10 \%$ from target);

0 : static position (deviation $\pm 1 \%$ from target);

+ : less improvement or improvement in some conditions (improvement between the rate of $1 \%$ and $10 \%$ of the target);

++ : Intense improvement (improvement of more than $10 \%$ of the target).

An urban monitoring table of the Heidelberg plan is presented in Table 3.

Lastly, achievements of the aims were calculated. According to the deviation from the target or improvement of the target, the plan is reconsidered and the decisions are updated.

\subsection{Evaluation of the examples from US and Europe}

The common characteristic of the selected US and European urban plans is that sustainability plays a key role in all policies and decisions taken in the plans. As well, these plans have some other common characteristics among which the most important ones are the participation principle and monitoring stages. Other similar characteristics of these sustainable urban plans are the matrices that integrate established scenarios and environmental values and that try to measure how these environmental values are changing toward differentiated decisions and policies. These matrices 'Sustainability Matrix', 'Urban Monitoring Matrix', and 'Policy Evaluation Matrix' provide important advantages through feedback within the decision-making processes.

In all plans, sustainability is considered within the application process, instead of its philosophical dimension. In this respect, sustainability is sought to be realized by several decisions, such as mixed use, alternative energy and transportation, recycling, and waste management.

In all US examples, smart growth principle is primary and principles like mixed use, compact building design, differentiated housing types, preservation of open areas, supply of environmentally sensitive transportation modes, and achievement of participation of all groups are accepted.

From the evaluation of the US examples, the following common points are revealed:

- giving significant importance to participation in every stage of the planning process;

- accepting sustainability as the basic reference for smart growth;

- taking sustainability in the application process rather than a philosophical dimension; 
Table 3: An example of an urban monitoring table: Heidelberg plan through sustainable development.

\begin{tabular}{|c|c|c|c|c|c|}
\hline Target & Indicators & 2000 & 2003 & Difference & Classification \\
\hline \multirow{4}{*}{$\begin{array}{l}\text { Economic } \\
\text { use of settled } \\
\text { areas, } \\
\text { decrease of } \\
\text { land } \\
\text { consumption }\end{array}$} & $\begin{array}{l}\text { Percentage of settlement } \\
\text { and traffic areas in } \\
\text { common region }\end{array}$ & 29.2 & 29.4 & 0.2 & 0 \\
\hline & $\begin{array}{l}\text { Size (ha.) of potential } \\
\text { residential area in spatial } \\
\text { arrangement model }\end{array}$ & 127.2 & 103.8 & -23.4 & + \\
\hline & $\begin{array}{l}\text { Size (ha.) of potential } \\
\text { commercial area in } \\
\text { spatial arrangement } \\
\text { model }\end{array}$ & 196.9 & 177.9 & -19 & + \\
\hline & $\begin{array}{l}\text { Percentage of completed } \\
\text { houses to total houses in } \\
\text { vacant land }\end{array}$ & 93.5 & 100 & 6.5 & ++ \\
\hline $\begin{array}{l}\text { Economic use } \\
\text { of settled } \\
\text { areas, decrease } \\
\text { of land } \\
\text { consumption, } \\
\text { intense } \\
\text { settled areas }\end{array}$ & $\begin{array}{l}\text { Urban citizen per } \mathrm{km}^{2} \text { and } \\
\text { number of responsible } \\
\text { job providers } \\
\text { contributing to social } \\
\text { security }\end{array}$ & 6.992 & 7.017 & 25 & 0 \\
\hline $\begin{array}{l}\text { Little walkable } \\
\text { city }\end{array}$ & $\begin{array}{l}\text { Percentage of citizens have } \\
\text { an access to market on } \\
\text { pedestrian road (max } \\
\text { distance from home is } \\
500 \mathrm{~m} \text { ) }\end{array}$ & 87.8 & 86.2 & -1.6 & - \\
\hline
\end{tabular}

Source: http://www.heidelberg.de/servlet/PB/show/1149617/12_pdf_Sustainablility\%20

Report\%202.pdf.

- emphasizing education of the public in order to diffuse sustainability as a social vision;

- efforts to realize the principles of sustainability in all fields of urban planning (mixed use, alternative transportation, environmental protection, energy, wastes, etc.);

- determination of options of target, strategy, and actions;

- supporting urban plans with application matrices;

- controlling plan applications with monitoring processes.

Concerning the European examples, it is obvious that the application of sustainability in urban development plans differs. Legal and administrative structures play important role in this differentiation; for example, the role of central governments in urban plans varies greatly among countries. In addition, the rates of participation in planning vary from country to country.

The most striking aspect of the European examples is the matrices that evaluate development related to the environmental values, and especially take place in monitoring stage of the plans. 
Monitoring stage is an important and inevitable part of these plans as flexibility is sought to be achieved through this process. Flexibility is also an important characteristic of sustainable urban plans in all examples.

\section{SUSTAINABLE URBAN PLANNING IN TURKEY}

Turkey is one of the countries that support the international sustainability efforts from the beginning. For instance, an important milestone for the international sustainability efforts Habitat II Conference in 1996 was held in Istanbul, Turkey, with the efforts of several bureaucrats and technocrats.

Although there are several efforts about sustainability in Turkey, it is hardly related to urban planning. Besides, there are many structural problems concerning the Turkish urban planning tradition. Thus, in this part of the study, these subjects are explained and a new sustainable urban planning model is presented.

\subsection{Sustainability efforts in Turkey}

Sustainability efforts in Turkey first took place in an intense manner after the Rio Conference in 1992 and Habitat Conference in Istanbul in 1996. Local Agenda 21 applications in Turkey were started in 1997 with the support of the United Nations Development Programme (UNDP) as a project study. With the support of the state, this project study was first converted into a LA 21 program and after the generation of City Councils and governance efforts in Turkey [43]. In this respect, the fourth stage of the programme declared in 2007 called for the localization of UN Millenium targets with the help of the LA 21 governance network [44]. The last and the continuing stage is strengthening City Councils and supporting them for acting as local democratic governance mechanisms.

In all these stages of the project and in the next program, the emphasis has been on local authorities and governance efforts. 'Urban Planning aspects' in order to maintain sustainable urban development and even the sustainable urban development itself are not included in the related documents [43-47]. The concept "sustainable urban development" takes place only in the section that describes the Aalborg Meeting.

Besides, it would be accurate to state that urban planning practices in Turkey are far from maintaining sustainable urban development due to the several structural problems.

\subsection{The contemporary Turkish urban planning tradition and sustainability}

The Turkish urban planning system could be characterized as a comprehensive top-down approach. There are four main hierarchical stages in the Turkish planning system: (i) National Strategies and Development Plans, (ii) Regional Plans, (iii) Environmental Order Plans, and (iv) Construction and Development Plans of localities. At the top of this hierarchy, there are the national plans that are mostly strategic plans concerning policies and action plans. The regional plans are prepared at map scales over 1/100.000 and accepted as an ambiguous plan level within the Turkish planning system [48]. The Environmental Order Plans determine the condition of and overall land-use decisions considering housing, industry, agriculture, tourism, and transportation related to national and regional policies. The Environmental Order Plans are often applied within the limits of provinces at map scales of 1/50.000 and 1/100.000 depending legally on the regulation with Code number 27051, accepted in 2008 [49]. The Construction and Development plans are divided into Master (Nazim) plans corresponding to the map scales of $1 / 25.000$ and 1/5.000 and the "construction application plans' at 1/1.000. The last ones are the application plans, considered as the final stage of city plans, and are produced for every type of urban settlement with a population over 2000.

It is indicated that these application plans neglect urban identity and ecological values in cities [50]. There are no visible efforts toward sustainability in this type of plans [50]. 
There is a common thought that there are some structural and organizational problems about the Turkish planning system, and thus the system should be restructured [51]. The necessity to change the practice of spatial planning seems to be a common view of all stakeholders. The bottlenecks of the Turkish planning system that should undergo a change could be listed as [51]:

- lack of a spatial planning system integrated with national development planning,

- lack of a cooperative planning vision and strategy,

- partial implementations in planning and authorization conflict,

- numerous authorities for the same spatial scale,

- lack of coordination between institutions,

- deficiency of conventional urban planning systems within developing social structure.

The legislative system concerning urban planning inevitably plays an important role in these bottlenecks. Despite some other structural problems, in terms of sustainability there is no notion about sustainability in the main Law of Construction and Land Development accepted in 1985 [52]. This law is accused of reducing city development to a simpler construction activity [50] as it considers city development only in its physical context. On the other hand, in the text of the framework for the change of this law, sustainability concept takes place in four parts. In this new framework, to maintain healthy, secure and sustainable living environments is aimed [53]. Apart from this, a new spatial strategic plan concept is introduced to maintain sustainable development with participative processes (article 8). Also, it defines the Environmental Order Plans to maintain sustainable regional development. Lastly, it refers to sustainable rural settlement plans [53]. This is not the first law framework in which sustainable urban development is included. Also, Environmental Law of 2006 determines maintaining sustainable development as the main aim of the law (article 1). It states that all authorities that make land-use decisions should regard sustainability (article 3) [54].

With reference to sustainable urban development, the Turkish urban planning system could be criticized in terms of sustainability consciousness, existence of participation, monitoring processes used in planning, and use of several sustainability indicators.

Concerning participation, the current Turkish planning traditions and laws do not enable a participatory process. It is not even defined in the Law of Construction and Development accepted in 1985. The planning system depends on master plans, as explained above. The Master Plans are announced on the municipality boards and their implementation takes place after their approval by the Municipal Council. The citizen participation stage is only enabled once the master plans are announced on board. Citizens only investigate them and make an opposition if they believe that their rights are overridden. Moreover, there is no technical support given to citizens when they examine the plans.

In relation to monitoring process, it is seen that there is no such application in planning processes in the current formal planning system. Monitoring is not possible as the system allows partial planning through "additional revised master plans" which are made at district scales, within comprehensive planning processes. This process deteriorates the comprehensive planning approach.

Concerning the Turkish urban planning system, there are no sustainability indicators within the entire urban planning formation.

\subsection{A new sustainable planning approach for the Turkish urban planning process}

Besides its several structural problems, the contemporary Turkish urban planning system has to adapt itself to sustainable urban development. Sustainable urban planning necessitates a different 
type of planning different from traditional/conventional urban planning approach. Several changes in contemporary planning system have to be realized.

The Turkish planning system is a comprehensive one in which the top-down approach is dominant. This signifies that all the upper scale decisions affect the lower ones and an authority control can be achieved on the entire planning process. It is possible to adapt this system to sustainable urban planning only by adding some procedural improvements. The keywords in this process are participation, sustainability indicators, and monitoring.

As urban land rent is an important source of unequal wealth distribution and an important problem of urban planning in Turkey, the best solution would be to adapt the comprehensive urban planning to sustainable urban development. The comprehensive approach seems to be the best one to control the planning and application process in Turkey, even though it has several bottlenecks and as a result, partial local plans are on the agenda. Radical changes in the planning system, for example, full citizen participation in urban design, might not be possible in the short run due to the conservative social and the fragile economic structure. Innovations like passive or semi-active participation, indicators, and monitoring in the existing planning system would greatly contribute in the short run.

Participation should take place at the early stages of planning in which experts act as guides. This could be achieved by passive participation by the surveys and interviews, as well as by the semiactive participation of selected volunteer citizens in design processes with the guidance of urban planners at the lower scales such as district levels.

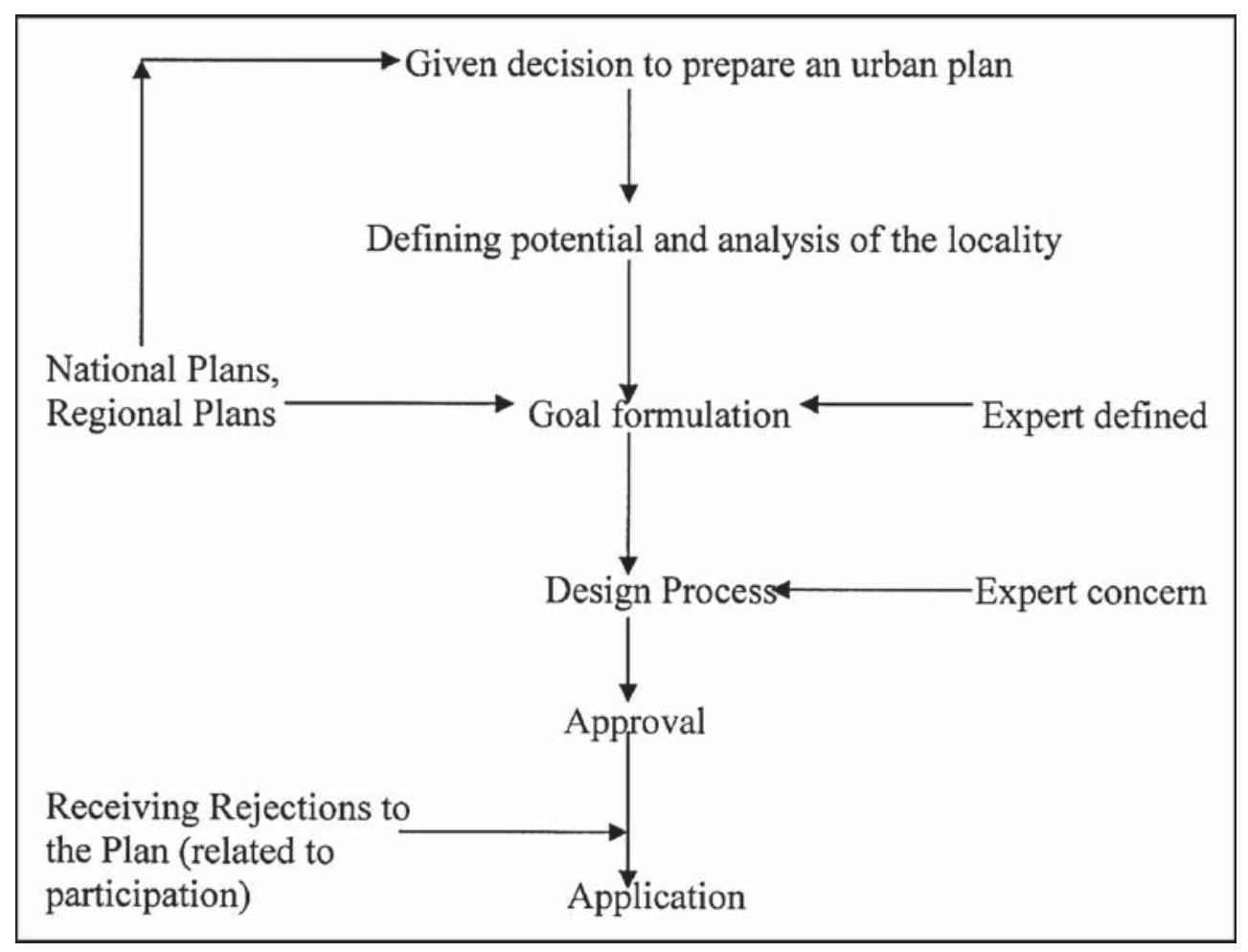

Figure 1: Simplified traditional urban planning process in Turkey. 


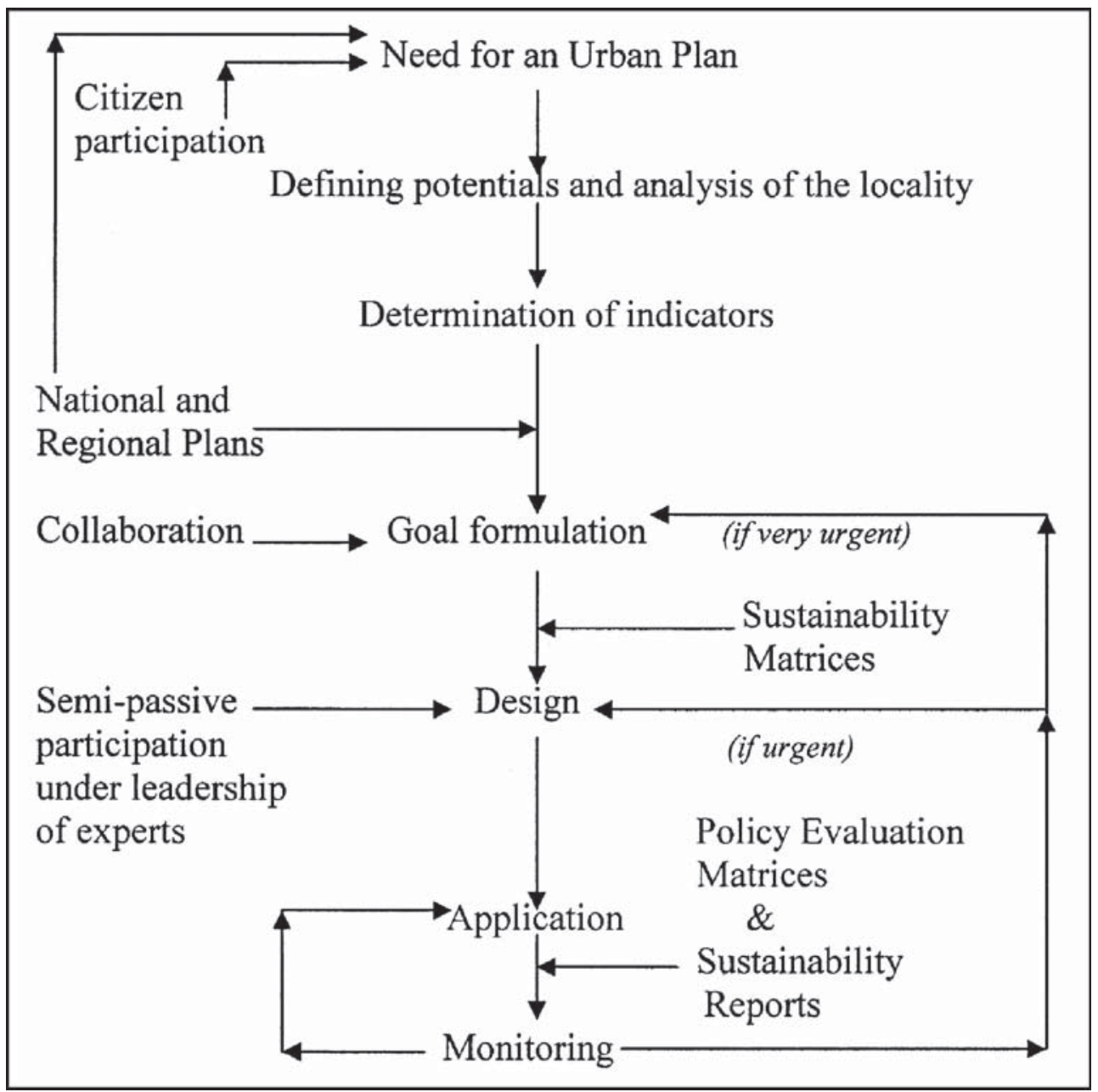

Figure 2: Proposal of the sustainable urban planning process for Turkey.

Introducing monitoring does not require any radical improvements in the existing system but it necessitates serious procedural adjustments. One of the most important deficiencies of the Turkish urban planning system is the lack of monitoring processes in the application phase of urban plans. The absence of monitoring is one of the reasons for the increase in the number of the partial development plans, and thus the loss of feasibility of decisions of comprehensive planning.

Monitoring could be easily achieved once a set of sustainability indicators is defined. It would be easy to evaluate the results of urban plans using these indicators. Adapting these indicators to the urban planning system does not lessen the significance of experts; on the contrary, the existence of indicators would ease the control of the process by planners.

Within the process of sustainable urban planning, sustainability and policy evaluation matrices will contribute to the evolution of sustainable urban planning. Preparing the appropriate legal basis is at the center of the discussion to maintain a sustainable urban planning approach in Turkey. 
The main authority in the process should be the local authorities, who will have the responsibility of leading the entire process. Moreover, they should be responsible about managing citizen participation. Local authorities or the unions of local authorities should also be responsible for preparing regional plans. While the national plans prepared by the central government affect the decision-making at local levels on a policy level, they should not directly affect the local design efforts.

Figs 1 and 2 show the simplified traditional urban planning process in Turkey and the proposal for the sustainable urban planning process for Turkey.

\section{CONCLUSIONS}

Sustainability is an important concept for the future of cities as it is definite that urban civilization cannot proceed with its conventional habits and characteristics of the contemporary mankind. The concept of sustainability could be seen as "life preserver" for the future of the whole world civilization.

Cities become the main operation area of sustainable development, as the sustainable development concept is nearly transformed into 'sustainable urban development'. Urban sustainability becomes a critical issue for the future of cities as urban population is continuously increasing. In this respect, it seems essential and inevitable that urban planning tradition and conventional urban planning processes should change through sustainability for a healthy future of cities. There are some traces of this kind of change, especially in the developed countries. Since the first international efforts on this issue, in the late 1980s, the developed countries have started to change their planning procedures according to sustainability and toward an emerging new planning paradigm. The primary factors in changing the urban planning paradigm are citizen participation, identification of sustainability indicators, and monitoring process and feedbacks in the planning process.

Whereas the planning processes in the developed world could be easily adapted to sustainable urban development, it is not easy in the developing countries for several economic and social reasons. On the one hand, planning application levels are different and vary from country to country according to their development levels, socio-economic conditions, and legal and administrative aspects. On the other hand, the processes in the developed world could only be adapted to other countries with respect to their economic and social situations. Sustainable urban planning examples of the developed countries could be a model for the others toward making sustainable urban plans for sustainable urban development. In this respect, some sustainable urban planning examples from the USA and Europe were presented in this article as a model for developing sustainable urban planning in Turkey.

The common point of these examples is the mid-size cities where all these successful sustainable plans were applied. However, it is a different and a broad research topic whether the size of city has an impact on the success degree of a sustainable urban plan.

In spite of several differences between Turkey and the USA and the developed European countries, there are some hints from these examples for structuring sustainable urban planning for sustainable urban development in Turkey. Participation, indicators, monitoring, and evaluation matrices could be utilized as helpful procedures or tools adapted to the comprehensive planning approach in Turkey, as this type of action could be the best model for Turkey in the short and middle run. Comprehensive urban planning seems to be the best approach for Turkey in order to prevent the inequitable rent distribution created from the urban land.

The most important conclusion is that, in order to realize these modifications in the Turkish urban planning system, the necessary legal and organizational arrangements should be completed right away. 


\section{REFERENCES}

[1] Lewis, H., Sustainability, the Complete Concept, available at http://www.naturalhealthsciencenews.org/Sustainability-Environment- Healthcare (accessed 18 January 2011).

[2] Kumar, B.D. \& Kumar, A., Sustainability: exploring the ancient India and current practices. Journal of Sustainability, 2(3), pp. 19-27, 2010.

[3] History of Sustainability, available at http://www.danzergroup.com/fileadmin/files_group/ docs/history-of sustainability_en.pdf (accessed 11 January 2011).

[4] A Short History of Fishing, available at http://openlearn.open.ac.uk/mod/resource/view. php?id=391579 (accessed 11 January 2011).

[5] Declaration of the U:N. Conference on the Human Environment - 1972, available at http://www. unep.org/Documents.Multilingual/Default.asp?documentid=97 \&articleid=1503 accessed 11 January 2011).

[6] Habitat: United Nations Conference on Human Settlements, Vancouver, available at http:// www.unostamps.nl/subject_habitat_conference_i.htm, 1976 (accessed 11 January 2011).

[7] Brundtland Report, available at http://daccessddsny.un.org/doc/UNDOC/GEN/N87/184/67/ IMG/ N8718467.pdf (accessed 18 January 2011).

[8] Olofsson, J., Sandow E., Towards a More Sustainable City Planning: case Study of Dar es Salaam, Tanzania, Minor Field Studies Report, Umea University, Department of Social and Economic Geography, 2003.

[9] United Nations, Sustainable Urban Development: A Regional Perspective on Urban Governance, Economic and Social Commission for Western Asia, New York, 2001.

[10] Hong Kong Declaration on Sustainable Development for Cities, available at http://www. un.org/esa/sustdev/csd/csd12/HK_declaration.pdf (accessed 18 January 2011).

[11] Van Geenhuisan, M., Nijkamp, P., Sürdürülebilir Kenti Nasıl Planlamalı? Toplum ve Bilim Dergisi, translated by Duruöz Nil, No: 64-65, pp. 129-140, 1994.

[12] Mengi, Ayegül, ALGAN, Nesrin, Küreselleşme ve Yerelleşme Çağında Bölgesel Sürdürülebilir Gelişme - AB ve Türkiye Örneği, 1. Baskı, Siyasal Kitabevi, Ankara, 2003.

[13] Rosales N., Towards a design of Sustainable Cities: Incorporating Sustainability Indicators in Urban Planning, 46th IsoCarp Congress, Nairobi, Kenya, 2010.

[14] U.N. HABITAT, Planning Sustainable Cities: Global Report on Human Settlements 2009, U.N. Human Settlements Programme, Sterling, USA, 2009.

[15] Wheeler Stephen, Planning For Sustainability: Creating Liveable, Equitable and Ecological Communities, Rouledge, New York, 2004.

[16] Haughton, Graham, Developing sustainable urban development models, Cities, 14(4), pp. 189-195, 1997. doi:http://dx.doi.org/10.1016/S0264-2751(97)00002-4

[17] Tsenkova, Sasha, Sustainable Urban Development in Europe: Myth or Reality, Events and Debates, Blackwell Publishers Ltd., USA, 1999.

[18] U.N. HABITAT, Planning Sustainable Cities: UN-Habitat Practices and Perspectives, U.N. Human Settelements Programme, Kenya, 2010.

[19] Kayasü, Serap, Yeni Planlama Paradigması ve Kurumsallaşma Süreçleri Üzerine, Planlama, TMMOB Ş.P.O. Yayını, No: 2002/4, pp. 52-55, 2003.

[20] Naess, Peter, Urban planning and sustainable development. European Planning Studies, 9(4), pp. 503-523, 2001.

[21] Healey, P., Collaborative Planning. Shaping Places in Fragmented Societies, Macmillan Press, Houndmills/London, 1997.

[22] Hague, Cliff, Planning for Sustainable Development in Urban Communities, Commonwealth Association of Planners, Belfast 2000. 
[23] Amado, M.P., Santos C.V., Moura E.B. \& Silva V.G., Public participation in sustainable urban planning. World Academy of Sciences Engineering and Technology, 2009.

[24] The Aalborg Commitments Implementation Guide: A 5-step Approach, available at http:// www.localsustainability.eu/fileadmin/template/projects/localsustainability_eu/files/ACTORGuide_english.pdf (accessed 18 January 2011).

[25] World Health Organisation (WHO), Towards a New Planning Process, A Guide to Reorienting Urban Planning Towards Local Agenda 21, European Sustainable Development and Health Series, 1999

[26] Eryildiz, Semih, Çevreyi Geliştirici Kentleşme, Basılmamış Doktora Tezi, (Unpublished Doctorate Thesis) Ankara Üniversitesi, Sosyal Bilimler Enstitüsü, Kamu Yönetimi ve Siyaset Bilimi Kent ve Çevre Bilimleri Anabilim Dalı, Ankara, 1994.

[27] Stapleton Community Green Book, available at http://www.stapletondenver.com/community/ greenbook/ (accessed 29 June 2006).

[28] Asheville Development Plan - 2025, available at http://www.ashevilleciviccenter.com/planning/plan2025/introduction.pdf (accessed 25 June 2006).

[29] Asheville City Plan, available at http://www.ashevillenc.gov/web/FinalPlan4.pdf (accessed 30 June 2006).

[30] Stapleton City Development Plan - 2003, available at http:www.stapletondenver.com/pdf/ misc/Stapleton_Sustainability_Plan.pdf (accessed 29 June 2006).

[31] http:/www.partnerships.stockholm.se/new_tavlande_index.html (accessed 30 June 2006).

[32] http://www.ci.austin.tx.us/sustainable/sustdev.htm (accessed 24 November 2005).

[33] http://www.ci.austin.tx.us/sustainable/matrixintro.htm (accessed 24 November 2005).

[34] http://www.ci.austin.tx.us/sustainable/madm.htm (accessed 24 November 2005).

[35] World Health Organisation (WHO), Towards A New Planning Process; A Guide to Reorienting Urban Planning Towards Local Agenda 21, European Sustainable Development and Health Series: 3, 1999.

[36] Cork City Development Plan Report, available at http://www.corkcitycouncil.ie/ourservices/ planning/pdf/Section_2.pdf (accessed 04 July 2006).

[37] Cork City Development Plan, available at http://www.corkcity.ie/ourservices/planning/developmentplan/download.html (accessed 04 July 2006).

[38] Woyseth-Dunin, Halina, Image - Making As A Step For The Master Plan Of A City In Norway, Development of Kabul, Reconstruction and Planning Issues, 10th Architecture\&Behaviour Colloquim, 4-7 April 2004, eds. Babar Mumtaz, Kaj Noschis, Imprimerie Chabloz S.A., Lausanne, Switzerland, pp. 119-124, 2005.

[39] http://www.heidelberg.de (accessed 04 August 2006).

[40] http://www.heidelberg.de/servlet/PB/menu/1090917/index.html (accessed 04 August 2006).

[41] Agenda 21 for German Cities, available at http://www.un.org/esa/agenda21/natlinfo/countr/ germany/inst.htm (accessed 04 August 2006).

[42] http://www.heidelberg.de/servlet/PB/show/1149617/12_pdf_Sustainablility\% 20Report\%202. pdf (accessed 14 August 2006).

[43] Emrealp, Sadun., Yerel Gündem 21 Uygulamalarına Yönelik Kolaylaştırıcı Bilgiler El Kitabı, IULA EMME (UCLG-MEWA) Publication, 2005.

[44] Türkiyede Yerel Gündem 21 Yönetişim Ağı Kanalıyla BM Binyıl Kalkınma Hedeflerinin Yerelleştirilmesi (LA 21 for Turkey Fourth Stage), available at http://www.habitat.org.tr/ gundem21/43-yerelgundem21/53-yerel-gundem-21-dorduncu-asama.html (accessed 11 January 2011). 
[45] Türkiye'de Yerel Gündem 21'lerin Uygulanması (II. Aşama) Uygulama Dönemi: 2000-2003 Proje'nin ortaya çıkışı (LA 21 Turkey Second Stage), available at http://www.habitat.org.tr/ gundem21/43-yerelgundem21/51-yerel-gundem- 21-ikinci-asama.html (accessed 11 January 2011)

[46] Türkiye'de Yerel Gündem 21 Yönetişim Ağı Yoluyla BM Binyıl Bildirgesi Hedefleri ve Jonannesburg Uygulama Planının Yerelleştirilmesi Projesi (LA 21 for Turkey Third Stage), available at http://www.habitat.org.tr/gundem21/43-yerelgundem21/52-yerel-gundem-21-ucuncuasama.html (accessed 11 January 2011).

[47] V. Aşama - Kent Konseylerinin Güçlendirilmesi Raporu (LA 21 for Turkey Fifth Stage), available at http://www.ulusalgenclikparlamentosu.net/dokumantasyon/yg-21/v-asama (accessed 11 January 2011).

[48] Ersoy Melih., İmar Mevzuatımızda Planlama Kademeleri ve Üst Ölçek Planlama Sorunu, avilable at http://www.tepav.org.tr/sempozyum/2006/bildiri/bolum3/3_2_ersoy.pdf, 2006 (accessed 04 October 2009).

[49] Regulation Numbered 27051, available at http://rega.basbakanlik.gov.tr/eskiler/2008/11/ 20081111-7.htm (accessed 01 August 2009).

[50] Ercoșkun, Y., Özge, Sustainable city plans against development plans, G. U. Fen Bilimleri Dergisi, 18(3), pp. 529-544, 2005.

[51] Kentleşme şurası, Bayındırlık ve İskan Bakanlığı, Mekansal Planlama Sistemi ve Kurumsal Yapilanma Komisyonu Raporu, Ankara, 2009.

[52] İmar Kanunu (Law of Land Development and Construction Numbered 3194), available at www.bayindirlik.gov.tr/turkce/html/kanun108.htm (accessed 11 January 2011).

[53] İmar Kanununda Değişiklik Yapılmasına Dair Kanun Taslağı (Framework for Change of Law of Land Development and Construction), available at www.hkmo.org.tr/genel/bizden_detay. php?kod=6727 (accessed 11 January 2011).

[54] Çevre Kanunu (Environmental Law), available at http://www2.cevreorman.gov.tr/yasa/k/2872. doc (accessed 11 January 2011). 